\title{
Review \\ Promoting the Solar Industry in Ghana through Effective Public-Private Partnership (PPP): Some Lessons from South Africa and Morocco
}

\author{
Samuel Amo Awuku 1,*(D), Amar Bennadji ${ }^{2}$, Firdaus Muhammad-Sukki ${ }^{3}$ (D) and Nazmi Sellami ${ }^{3}$ \\ 1 School of Engineering, Robert Gordon University, The Sir Ian Wood Building, Garthdee Road, \\ Aberdeen AB10 7GE, UK \\ 2 School of Architecture and Built Environment, Robert Gordon University, The Sir Ian Wood Building, \\ Garthdee Road, Aberdeen AB10 1FR, UK; a.bennadji@rgu.ac.uk \\ 3 School of Engineering \& the Built Environment, Merchiston Campus, Edinburgh Napier University, \\ 10 Colinton Road, Edinburgh EH10 5DT, UK; f.muhammadsukki@napier.ac.uk (F.M.-S.); \\ N.Sellami@napier.ac.uk (N.S.) \\ * Correspondence: nanaawuku021@gmail.com
}

Citation: Awuku, S.A.; Bennadji, A.; Muhammad-Sukki, F.; Sellami, N. Promoting the Solar Industry in Ghana through Effective

Public-Private Partnership (PPP):

Some Lessons from South Africa and Morocco. Energies 2022, 15, 17. https://doi.org/10.3390/en15010017 Academic Editor: Yuriy Bilan

Received: 21 November 2021 Accepted: 15 December 2021 Published: 21 December 2021

Publisher's Note: MDPI stays neutral with regard to jurisdictional claims in published maps and institutional affiliations.

Copyright: (C) 2021 by the authors. Licensee MDPI, Basel, Switzerland. This article is an open access article distributed under the terms and conditions of the Creative Commons Attribution (CC BY) license (https:// creativecommons.org/licenses/by/ $4.0 /)$.

\begin{abstract}
Over the past decades, solar energy has gained much attention in Ghana, especially after the 2012-2016 power crisis. The government through Public-Private Partnerships (PPPs) has attempted to increase the shares of solar generation to augment its efforts in reducing the energy deficit of the country, especially in remote and off-grid communities. However, the extent to which PPP has been utilized as a viable tool for solar sector development in Ghana is questionable. This study discusses the current state of PPPs in Ghana's solar industry and compares how it has been efficiently used as a tool to promote the solar industry in South Africa and Morocco. Fundamental theories such as Altruism, Game, Principal-agent, and Pareto Optimality (PO) were used as analytical tools to examine how PPPs are handled in the selected cases. The study ascertains that the Game and PO are applicable theories that have guided SA and Morocco's solar infrastructural development. This study discovered that PPP has been efficiently used in SA and Morocco to push its solar industry to be among the best in the world and Ghana can perfectly emulate it. The study further reveals that the Principal-agent analogy and altruistic intent of the Ghanaian government tend to discourage Private sector participation in the solar industry. It further suggests the Pareto Optimality, Game approach, and a win-win transparent attitude towards PPPs. This study recommends a well-developed PPP structure and law for Ghana. It encourages transparency and discourages partisan preferentialism to increase PPPs in Ghana's solar industry.
\end{abstract}

Keywords: Public-Private Partnerships; Ghana; South Africa; Morocco; solar energy

\section{Introduction}

Solar energy is indisputably one of the most viable and clean energy sources humanity has ever discovered. Issues such as climate change and other economic dynamics have not just made it a tangible option but also a momentous resort for energy security needs. Evidentially, the solar sector has a proven track record of fast-expanding technology making it capable of both domestic and industrial energy needs. Ghana has had its first share of solar photovoltaic technology on the African continent but at a steady and staggering pace. Fundamental issues such as poor Public-Private Partnerships (PPP), inadequate legislation and policy frameworks, socio-cultural factors, and political climate have been identified by various researchers as hindrances to the blow-up of solar energy in Ghana. The solar industry in Ghana has been predominantly dominated by the private sector until recently when the hype for renewable energy deployment has become the order of the day for various governments, due to the issue of climate change. It is therefore imperative to consider a holistic partnership approach between the public and private sectors in Ghana's solar industry. 
This paper focuses on Public-Private Partnerships in Ghana's solar sector. It discusses the solar energy industry in Ghana by mainly extrapolating from the Public-Private Partnership experiences of South Africa (SA) and Morocco. SA and Morocco have been chosen because of their significant achievements in the solar industry through PPPs. Major solar projects have been recorded through effective PPPs in both countries, boosting their renewable energy shares and contributing to energy security. These selected countries have demonstrated some advanced knowledge and structure in handling PPPs, therefore making them better models worthy of emulation. However, the downsides of PPPs in both countries are also worthy of acknowledgment since lessons can be drawn from their shortcomings as well. This paper extensively discusses the potentials for Ghana's solar industry and draws from the PPP experiences of SA and Morocco. It relies on applicable theories such as "Parito Optimality, Game, Altruism, and Principal Agent" to analyze the successes and shortfalls of the chosen countries.

PPP is a viable tool that can be potentially adapted to boost infrastructure development, especially within Ghana's solar energy sector. Although several PPP agreements exist in Ghana for various projects, the extent of "due-diligence" and quality is questionable. Most of these projects are left half-finished or uncarefully planned. The scanty nature of these agreements has cost great loss to the country; hence a practical policy intervention is necessary. Although this paper does not provide qualitative exploratory evidence, or adopt a rigorous scientific methodology, it makes a considerable effort to highlight some success stories of SA and Morocco's solar sector and further draws lessons for Ghana by adopting a review analytical approach.

The next section shall discuss Ghana's potentials for solar energy generation and development, its impact on energy transition, and the significance of Public Sector Participation (PSP). The next shall discuss the theory of PPP extensively. The next shall discuss PPPs in South Africa (SA) and Morocco by considering some success stories, failures, and theoretical perspectives. The next shall consider some lessons Ghana can learn from the PPP experiences of SA and Morocco. The next highlights some lessons that can be drawn from SA and Morocco and makes some key policy recommendations for Ghana. The final section concludes.

\section{Ghana's Potentials in Solar Energy Generation and Development}

The future of Ghana's solar industry seems promising considering the recent addons in the sector. Solar has seen various faces of transformation in Ghana, despite major setbacks such as intermittency and volatility [1]. Currently, solar has become the most popular renewable energy source in Ghana and has great viability especially if the future security needs of the country are to be considered [2]. It is undeniable that Ghana's energy sector has a promising future if favorable policies are carved to promote solar technology. It is also worthy to note that electricity from solar PVs has gained a lot of prominence and attention in various economies across the world partly due to the general drop in the production cost [3]. This has made it relatively competitive to consider against other counterparts such as wind and hydro.

Ghana's solar energy generation potentials are enormous, considering the amount of sunlight received. Governments have kept the drive to improve electrification across the length and breadth of the country which to a large extent, has been successful with about $82.4 \%$ of the population having access to electricity [4]. Previously, Ghana was locked in to the use of hydropower for electrification but recent competitive prices in solar PVs have gradually inspired the desire for utility and off-grid solar systems among the general populace.

Various data gathered over the past 50 years by Ghana Meteorological Agency (GMA) and other authoritative bodies suggests that the amount of sunshine received in the various regions across the country is more than enough to generate the radiation needed for solar PV's to function to capacity with a potential error in radiation at $+/-5 \%$ [5]. The initial increase in solar was a result of various projects pushed across by the Ghana Energy Access and Development Project (GEDAP) funded by a host of donors [6,7]. Several campaigns 
have been made to push solar such as the "200 MW Government Goes Solar" by the Energy Commission with the sole aim of distributing free solar panels with up to $500 \mathrm{~W}$ capacity to especially off-grid remote communities in 2018 [8]. Indeed, it can be said that various solar projects are underway to augment the current energy sources in Ghana especially as the government is determined to uphold the renewable energy target of $10 \%$ by the year 2020 [9].

\subsection{Potential Impact of a Robust Solar Energy Industry in Ghana's Energy Transition}

The advancement of a country's energy needs is as crucial as issues of food security, health, and general well-being of the people since energy is a backbone of economic development and sustainability [10]. Growth in solar technology in the energy mix of Ghana is much anticipated, as various attempts to fully integrate solar started in the early 1990s [11,12]. In 2007, a once over-dependent low-income country migrated to middleincome status as the availability of energy services increased and economic activities boomed up [13]. The clean energy status of solar makes it a worthy addition, considering the impact of traditional biomass on human health and the environment which forms the major source of energy for heating and cooking in many developing countries, especially in Africa [14].

Unarguably, scarcity of energy resources has a direct bearing on the poverty levels of society with various pointers such as child mortality, rural-urban migration, lack of education, and basic healthcare in a developing country like Ghana. It is estimated that the average Asian and African spends about 1/3 of their salary on fuel which unfortunately is the traditional biomass [15]. The recent expansion of solar in Ghana is of great significance as it promises to introduce an overall reduction in the cost of energy, especially for off-grid poor communities. Indeed, targeting major solar projects in especially rural and off-grid communities could have a major impact on the livelihood of these rural households. Major mono-industrial towns could also benefit from a constant power supply and all the numerous environmental and economic advantages [16,17]. In a country where job creation is a major challenge for the government, a vibrant solar energy industry can employ thousands of people through direct and indirect jobs which will further reduce rural-urban migration.

\subsection{Underscoring the Significance and Impact of Effective Private Sector Participation (PSP) in Ghana's Solar Energy Industry}

Energy is as essential as water, agriculture, and health; therefore, the government must team up with the private sector to ensure sufficiency in production and sustainability across the nation. The significance and impact of effective Private Sector Participation (PSP) in Ghana's solar is enormous and visible especially considering the milestone Ghana has achieved in recent years.

PSP in Ghana's solar industry is not a new concept, considering its inception in the 1980s when missionaries and non-governmental organizations first introduced various forms of solar products for their personal use [18]. Solar received less attention from the government when it was brought at its initial stages due to the uncertainty of the technology. The technology mainly came with the installation of basic panels on the rooftops of various chapels and clinics, especially in remote areas. The most prominent government institutions to adopt solar through private partnership were the Ghana post and the then Ghana telecommunications [19]. These government agencies started replacing their defunct rickety diesel power plants with stand-alone solar power plants. Solar gradually proved with time to be a worthy option to be adopted by the government to alleviate energy poverty and hence its current progress.

One of the most overriding drivers for considering energy investments from the private sector is to have ingress into the copious volume of capital this sector has to offer. Access to sustainable electricity has been a hunch back for Ghana's economy for many decades partly due to the huge financial demands of the energy sector, as donor parties and the government is constantly unable to meet the financial requirement. The input of the 
private sector is therefore viewed as the most feasible option to augment the government in the quest to expand electricity through solar.

The overall benefits of PSP in Ghana's solar energy industry go far beyond the provision of capital for electrification. The few attempts government has made to pioneer solar projects in Ghana followed the same old trend of lack of expertise and inefficiency among the employers as well as negative attitude towards work. Ghana's electricity sector has witnessed various issues of property destruction and non-payment of bills due to an improper management system. The private sector on the other hand offers clear-cut managerial advantages, technical expertise, and overall efficiency in operation which the state-owned outfits lack [9].

Effective PSP in Ghana's solar energy industry could thus initiate both a boom in the initial capital requirement as well as enhance the human resources and technical expertise needed to ensure the success of the solar sector. Full PSP is therefore the roadmap to the growth of Ghana's solar industry.

\section{Theory of Public-Private Partnership in Africa}

The concept of PPP is broad, and many academic theories can be borrowed from various sectors. This section introduces the theory of PPP by explaining the concept, advantages and downsides, and Africa's approach to PPPs with emphasis on Ghana. The section also links theories such as the Principal-Agent, Altruism, Pareto Optimality, and Game to PPPs in Ghana, SA, and Morocco.

\subsection{Meaning, Benefits \& Downsides of PPP}

The idea of Public-Private Partnership (PPP) is to mainly create a mutually beneficial alliance between the government and private sector in handling key infrastructural issues confronted by the country. Various definitions can be given to PPP depending on the country and type of agreement [20], but the key dogma that runs through is that there is an established long-term contractual agreement between the government and a private entity with the overall intention of providing a specific project or service needed by the public, and the private entity bearing some of the risk involved [21]. The private sector is generally regarded as creative, entrepreneurial, self-motivated, ability to provide capital and a 'reservoir' of technical knowledge, therefore can fill in the gaps of the public sector [22]. The theory of PPP involves three major stakeholders, the "Private, Public, and Society". A simple theoretical structure is shown in Figure 1 below.

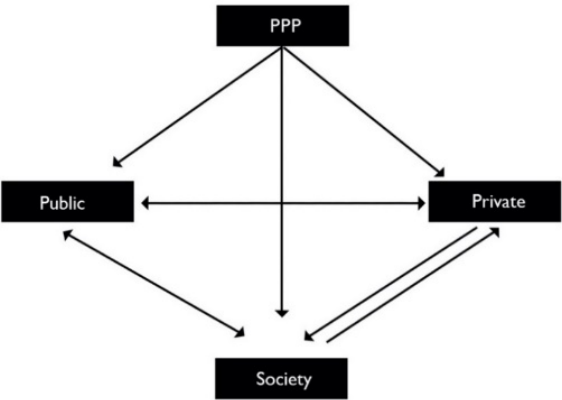

Figure 1. PPP Relationship between Stakeholders. Adapted from [23].

Many governments across the world have impediments that prohibit their progression in various sectors of the economy. The keys amongst these factors are financial and human capital. The government is therefore pressurized to rely on private sector alliances to fully live up to its mandate. Indeed, PPPs have become the new world order when it comes to public policy considering the rate at which many governments have easily switched to this approach [24]. There are several proven benefits of PPPs in developing countries where governments struggle to finance and handle major infrastructural projects. PPP helps in the reduction in the overall administrative expenditure on the shoulder of the 
government, sharing of risk, reduction in pressure on the government budget, the ability of the private sector to mobilize large resources to undertake pressing projects, enhancing open competition, and improving public services [25].

The private sector naturally operates from the cradle of maximizing profit [26] so of course, the cost of services will remain considerably high. Realistically, various governments across the world have constantly battled with giving the private sector room to operate and partake in major State projects although the State naturally cannot afford them due to tight budgets. This is what is known as "the privatization war" [27]. The idea of privatization war identifies three major categories; firstly, the allegory of the private sector choosing individualism over collectivism, secondly, the idea that policies that regulate public services are inefficient and mostly weak in checks and balances and thirdly, the war against privatization holds the perception that the private sector is on an agenda to rob the public purse with its high budgetary and overrated costs of projects for personal gains and an underlying intention of self-aggrandizement against the interest of the general populace and State. The push for privatization of specific projects in various countries is marred with several controversies due to all these valid concerns.

PPP's these days have opened a new chapter of industrialization in many developing countries, by becoming a mechanism for the development and provision of decent societies and a means of managing scarce and limited resources to give a facelift to otherwise underprivileged societies [28]. The visible benefits of PPPs make it a worthy practice for many governments to consider, especially in Africa.

\subsection{Understanding Public-Private Partnership in Africa}

In Africa, PPP is recognized as the most viable policy that can potentially rescue governments from the pile of underdeveloped infrastructure, technology, and service it is faced with. With the growing population and limited financial base of many governments in Africa, the electricity sector alone has a backlog of over 600 million people [29].

Various researches and assessments of PPPs in Africa are a combination of good and bad. In some instances, it worked, other times have been marred with complexities. It is therefore imperative that African states do not quickly jump on the bandwagon of PPP with the assumption that it is all breezy and a 'miracle drug'. PPP has a proven track record of reducing the conflict of full privatization since the government gets a perfect opportunity to deliver crucial amenities and services through the steering of a private contractor. At the end of the day, both the private entity and the government tends to benefit [30].

African countries such as Ghana, South Africa, and Morocco who are mainly mentioned in this context have all fully benefitted from PPPs over the past decades in various sectors of their economies. Major projects in transport, water, agriculture, energy, and health which have been swiftly undertaken by PPPs would have been a pain in the neck of many African governments considering the huge infrastructural deficits sitting between USD 130-170 billion per annum [31]. On the flip side, it has not been an all-smooth approach for Africans as there are several case studies of PPP failures [32]. For instance, in the Cenpower project in Ghana, Songas project in Tanzania, Lekki Expressway in Nigeria, and DTI campus accommodation project in South Africa [33]. Many researchers opine that PPP is the roadmap for Africa's infrastructural facelift but issues such as corruption, ineffective regulatory framework, undetailed feasibility studies, and overambitious projects must be addressed [30].

\subsection{Approaches to Public-Private Partnership in Africa with Emphasis on Ghana}

PPP must be regarded as an approach for efficiency and not just as a medium of financing and satisfying the nation's huge infrastructural deficits [34]. PPP in Ghana falls under an undetailed legal framework introduced in 2011 [34]. The commonest models are the Build-Operate-Transfer (BOT) and Design-Build-Operate (DBO) [35]. PPP means differently to various African countries and this informs the approach adopted. There is the notion that PPPs are hybridized; where both government and private sector resources are utilized for the realization of projects. Practically, PPPs have been categorized into five sub- 
stantive forms, which are: Partnering Strategically, Design-Build-Finance-Operate (DBFO), Partnerships and Joint Ventures, Franchising, Competitive Tendering, Contracting-Out and Public Leveraging [36]. Therefore, there are various approaches employed to execute PPPs. This section attempts to highlight key approaches to PPPs in the aforementioned selected African countries. According to [37], some applicable major approaches adopted for PPPs in many African countries are:

- Management of Contracts: This refers to the system where both parties agree on either short- or long-term projects such as rural roads, domestic water projects rural electrification. In this approach, the government makes the investment, and the private party either on a short- or long-term agreement maintains the facility and ensures its smooth running.

- Delivery of Projects through Small to Medium Scale Private Contractors: This refers to a state where the government relies on small to medium scale private entrepreneurs for basic social amenities. The contract is managed by a private party under the laws and regulations of the government.

- $\quad$ PPP User Fee: The government just assigns the private party to plan, finance, and maintain specific assets owned by the State. A concessionary agreement usually between 25-30 years is given after which the project is handed over to the government.

PPP has become the policy intervention in Ghana for the execution of many prominent projects since the Government of Ghana (GoG) showed full acceptance of this model in the early 1990s [38]. According to the Ministry of Finance and Economic Planning (MOFEP), the definition of PPP in Ghana is a contract between a private and public entity with a well-defined arrangement on shared responsibilities and risk allocation. Per this definition, three points stand out; firstly, there is a legal contract between the government through various Ministries, Departments, and Agencies (MDAs) and Metropolitan, Municipal, and District Assemblies (MMDAs) [39]. Secondly, the risk and responsibilities involved are shared between both parties, therefore there is corporation and agreement of the specific roles of parties [40]. Thirdly, the specific project is to be originally done by the government but in the event where the private sector delivers these projects on behalf of the government is clearly defined as PPP.

Best practices are encouraged in Ghana when it comes to PPP executions and key amongst them are broader stakeholder consultation, shared risk, identification of the right project, encouraging healthy competition, spotting the right project, and above all binding legal regulation [41]. Generally, there is no key underlining theory on PPP, but various theoretical ideologies have been carved from different backgrounds to build a better understanding of PPP's and a few of them are discussed below.

\subsection{Discussion of Applicable Theories}

\subsubsection{Principal-Agent Theory}

The theory of Principal-Agent (P-A) was initiated by Michael Jensen in the 1970s and later highlighted by other academics such as [42]. The theory delivers a solid ideological framework for accessing the rapport between an Agent and Principal to fully or partially undertake a task that the Principal is unable to accomplish due to certain factors. The theory has it that, ownership must be differentiated from control. This "differentiation of control" is naturally clear as there is a certain amount of authority that is passed on to the agent when a job is awarded by the principal. However, the principal remains the owner of the assets and carries liabilities in case of losses. Because both parties naturally seek to fully maximize gains, there is a high tendency for the Agent to make choices and decisions that is beneficial to them [43].

Any Agency Cost (Cost arising from poor choices and losses) will be shirked to the principal, since of course, the principal may not be able to constantly put the agent under surveillance. In many instances, the principal swallows these additional costs once it does not exceed the overall returns on the project [44]. Principal-Agent problems tend to cause a lot of hazards if not checked. Various PPPs have not been fully successful as 
issues of profit marginalization due to Agent's quest to maximize profit through non-linear pricing emerge [45]. This theory has a great bearing on PPPs as especially in many African countries, where various agreements have gone sour due to Principal-Agent problems. However, the underlying assumptions in agency theory on "Principal-Agent Personal Interest" may not be applicable in all contexts, therefore overdependency on this theory is objectionable since the intricacies of organizational behavior are discounted. It is therefore imperative that additional research must be conducted into this theory and its direct effects on PPPs [46].

\subsubsection{Altruism Theory}

The existence and activities of Non-Profit Organizations and alike NGOs cannot be croaked, especially in African countries that heavily rely on charity and aid [47]. This is the cradle from which the theory of Altruism stems. Altruism was developed in the late 19 th century by the great philosopher of Positivism, "Auguste Comte" [48]. The theory of Altruism can be likened to asceticism and social conscience that values the benefit of the other party than one's self. The desire to mollify the burden of other people is what this theory stands for [49]. In PPP, although both players have altruistic proclivities with the natural desire to do good to the other party, their actual behavior can be well addressed by the principal-agent theory as discussed above.

Various studies have identified that the risk-sharing proportions in many PPP agreements are dependent on their altruistic inclination. Governments usually will expect the private investors to act in an altruistic and non-profit status and this usually undermines the zeal of investors [50].

Interestingly, Altruism has become a deficiency in many States as many for-profit private partners have great commitment and a positive attitude towards the service or project they undertake because they run on the principle of increasing their share of profit. Contrary to the presupposition made by various researchers that the basic rationale behind PPPs cannot be without profit, others opine that indeed in the "societal norm", there is also a possibility that non-profit entrepreneurs who possess an underlying nature of altruism can be the new norm of society [51]. Altruism theory can be a fundamental prop for the public sector to benefit from the non-profit private entities especially if standardization and supervision are not compromised.

\subsubsection{Game Theory}

Game theory is a popular mathematical theorem that emerged as early as 1903 by John Von Neumann. Other researchers employed this theory in various fields of study with the basic rationale as a problem-solving and decision-making approach [52]. Game theory has been explained in various ways but the import is the use of mathematical models that have bearing on corporations and clashes existing between decision-makers assumed to be intelligent and rational. The "Game" in social context mainly refers to a situation in society that comprises two or more active players, similar to the decision theory [53].

The cooperation between the Public and Private sectors in PPP agreements makes it incumbent for parties to have a clear-cut understanding of the "PPP Game", as it adds up to a clearer definition of the structure of competition and cooperation among parties.

A clear-cut understanding of the PPP Game helps to reduce over expenses and the overall cost of projects. When PPPs are seen as cooperation and not some sort of "Game of Rivalries", a better outcome can be achieved [54]. However, it is worthy to note that the use of the Game in PPPs gives an impression of fairness "fair play" [22]. The utilization of gaming is ideal to help in fair and effective project handling and service provision.

\subsubsection{Pareto Optimality Theory}

Pareto Optimality (PO) is a Social Science theory developed by Vilfredo Pareto. It became popular in 1898-1923 for its underlining principle of economic optimization and efficiency. The theory proposes that an allotment can be regarded as effectual in the case 
where an action positions an individual at an advantageous state without leaving the other party worst off. PO has a bearing with game theory and forms an integral principle in economic decision-making and project allocation. On a general scale, the problems that come up due to the allocation of economic incentives have many potential outcomes if seen through the lens of PO. PO is said to have occurred when there is optimum utilization of meager resources for mutual benefit and not to the disadvantage of one party.

The PO theory is by no way suggestive of equal or impartial exploitation of resources. Critics say this theory undermines the principle of equity and does not offer a clear-cut approach to remediate prevalent inequality. In an instance where the income of one party increases not at the decrement of the other party, PO can be said to have occurred. PPPs can be analyzed through the lens of the Pareto Optimum theory, with the overall aim of mutual benefits and not one party gaining substantially at the decrement of the other party.

\section{Public-Private Partnership in SA and Morocco: Their Experiences, Successes, Failures and Theoretical Perspective}

The energy sector to a large extent has had its share of PPPs, which has helped reduce the overall energy poverty margins. This section focuses on two African countries; SA and Morocco, which have achieved greatly due to various favorable PPP agreements. Their experiences, successes, and failures are discussed with the overall motif of building a relevant case study for Ghana to emulate to promote its solar industry PPP agreements in the future.

\subsection{South Africa (SA)}

In SA, just like many other African countries, PPPs are accessed through the lenses of "Affordability, Appropriate risk transfer and Value for money" with various regulatory frameworks governing its execution. PPPs have been employed to facilitate the infrastructural development of SA, mainly ranging from roads, hospitals, social grants, educational facilities, among many others.

The solar industry was virtually non-existent in SA until 2011 when the industry started making positive strides with a focus on PV and thermal applications. Currently, solar forms a major proportion of SA's energy mix and has brought energy alternatives and security to otherwise remote and off-grid communities. Figure 2 shows the energy trend of SA from its 2010 levels to 2019. Various Renewable energy policies specifically targeting solar energy development have been adopted to give a facelift to the industry. The Solar Energy Technology Roadmap (SETRM) and South African Solar Thermal Technology Roadmap (SA-STTRM) give a detailed roadmap to solar energy development in SA [55].

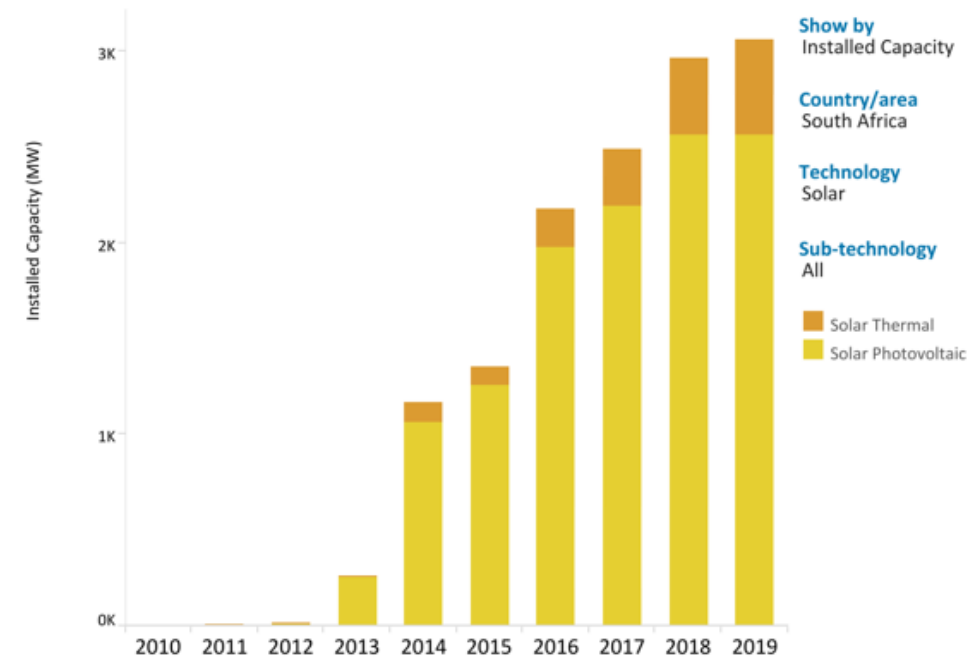

Figure 2. Solar capacity trends in South Africa [56]. 


\subsubsection{Experiences}

South Africa receives a high amount of sunshine all year round, with a daily average of 8 to $10 \mathrm{~h} \mathrm{[56],} \mathrm{making} \mathrm{it} \mathrm{a} \mathrm{viable} \mathrm{hub} \mathrm{for} \mathrm{solar} \mathrm{energy} \mathrm{generation.} \mathrm{Private} \mathrm{participation} \mathrm{has}$ been a backbone to the solar development of SA especially for water pumping, heating, and cooling, apart from the mainstream electrification. The quest to bridge the electricity gap has brought the participation of many private actors through various piloting programs in collaboration with the municipalities to ensure integrated electrification for rural and offgrid communities. In this instance, the private actors build and manage these solar systems and allow residents to pay in a long term to attenuate monthly bills. Solar partnerships have also gained popularity under the SA Department of water and Sanitation through its rural water-pumping program as well as heating and cooling [57].

One of the deep-rooted solar initiatives in SA which has attracted huge PPPs in recent times apart from the Utility-Scale solar system is the Roof-Top Project. Installing solar Photovoltaics (PVs) on rooftops of buildings has brought great relief to off-grid communities and offered energy alternatives for connected grids. The introduction of projects such as the GreenCape Smart Electricity Project by the government with the ultimate aim of promoting rural electrification and cutting download shedding has been a fertile ground for solar PPPs [58]. The SA solar market is bigger and open compared to Ghana partly due to the acceptance of the variety of technologies that invites and makes room for private partnerships.

Another area of SA's Solar industry that has emerged as a viable root for PPPs is the exploration of Solar electric cooking (PV e-cook). The overbearing difficulties in using traditional biofuel for cooking [59] make PV e-cook a better option. In turn, this technology has attracted investment and private sector participation which has made it popular and accepted by many rural homes. Exploring these new solar systems makes room for PPPs in SA due to the willingness and support given by the government. The next subhead discusses two of the most successful solar projects executed by PPP agreements that boosted SA's solar market, and further promoted electrification through the "Renewable Energy Independent Power Producer Procurement Programme" (REIPPPP).

\subsubsection{Successes}

Most of SA's solar projects are based in Northern Cape and the key successful ones to be discussed are the De Aar Solar Project and Kaxu Solar One.

\section{De Aar Solar Project}

De Aar Solar farm which was initiated under the government's Renewable energy policy; "Renewable Energy Independent Power Procurement Programme" (REIPPPP) sits on a 500-hector piece of land at the Northern Cape of SA with a total installed solar capacity of $175 \mathrm{MW}$. The project which was originally developed by Solar Capital, a subsidiary of the popular SA company Phelan Energy Group Ltd. had two phases; De Aar 1 and De Aar 2. The company had a PPA with SA's major power provider; Escom to supply power to the national grid to augment its effort in eradicating the electricity challenges confronted by the nation [60].

The first phase was swiftly completed and commissioned in 2014 but started functioning in 2016 with an initial capacity of about $85 \mathrm{MW}$ and phase two was also completed in April 2016 with a capacity of 90 MW. Over 700,000 solar panels have been deployed on the farm, giving over 100,000 homes in SA the advantage of benefitting from green electricity. This positions the project as one of the biggest in Africa and the world at large. The project has an operational expectancy of 20 years [61], and has so far impacted at least 350,000 students within its catchment area aside from its domestic electrification purpose. This project seeks to benefit and enrich communities within the scope of at least $50 \mathrm{~km}$, therefore creating jobs for over 400 locals apart from offering a reliable energy source [62].

The project is a PPP between Solar Capital and the SA state-owned energy company Eskom utilities [63]. An open bidding process was followed and solar capital emerged as the most competitive bidder for both phase one and two of the project. A viable 
procurement structure (REIPPPP) ("South Africa's Renewable Energy Independent Power Producer Procurement Programme") was adopted to follow a transparent approach to the deployment of the project. Maintenance of the project, ensuring value for money, and maximum returns on investment are equally crucial therefore Arup has been in partnership with Solar Capital to help in the construction and maintenance of this project and ensure that the necessary returns on investment are recouped. This competent hand gives some level of assurance and certainty that this project will be sustained through its lifetime and perform efficiently. All these key indicators make the De Aar project one of the most successful in the world and worthy of emulation.

\section{Kaxu Solar One}

Another milestone solar project in SA worthy of notice under PPP is the Kaxu Solar one project that sits in Poffader in the Northern Cape area. It has an installed capacity of $100 \mathrm{MW}$ with a history of being the earliest installed solar thermal power station to be commercially operated for electricity production [61]. The Kaxu project uses Concentrated Solar Power (CSP) and the parabolic trough technology to feed over 80,000 homes with clean electricity. After its inception in 2015, it has created over 4000 temporal and 80 permanent jobs [64].

The project is partly owned by Abengoa company, Industrial Development Corporation, and Broad-Based Black Economic Empowerment (BBBEE). The transparent procurement plan introduced by the government REIPPPP made this project a worthwhile venture, as beneficiaries now enjoy clean constant energy at affordable prices [65]. Advanced solar technology is being used for electricity production due to the profile of Abengoa, the partowners, and contractors. The Kaxu project gives a facelift to SA's solar industry especially as it uses the Parabolic trough technology, making it one of the most outstanding projects in Africa. The procedures regarding its PPP agreement, construction, and maintenance are worthy of emulation by Ghana.

\subsubsection{Failures}

Like many policies have challenges, PPPs have had their share of struggle in the SA solar industry despite the relatively plausible successes. Until the inception of Western Civilisation, private partnerships were not in sync with the regular development procedures as communal approach and support for each other was rather resolved. The adoption of a democratic system of governance came with PPPs which has by far seen the growth of the various sectors of the SA economy including the solar industry [66]. However, although SA has been a role model for PPPs in Africa, sometimes they are considered as being over abused. The private sector seemingly enjoys the lion's share against the general interest of the people due to personal interest. This results in the narrowing of PPP agreements to a selected category, which defeats the transparency agenda and competitive nature of PPPs [67]. Projects such as the 75 MW Mulilo Sonnedix Prieska which was built in 2016 have already started encountering operational and functional challenges due to the deployment of non-durable PV materials which could not withstand the high temperatures [68]. Cheap procurement for personal gains has rendered this project ineffectual.

\subsection{Morocco}

Solar in Morocco has a huge potential due to the sunny nature of the country. It is estimated that the average sunshine rate is $3000 \mathrm{~h}$ per annum and 3600 in desert regions [69]. Solar in Morocco has not just become a backbone to the energy sector but has reduced the nation's over-reliance on fossil fuels. A nation with an energy dependence rate of about $90 \%$ [70] has made great strides in reducing its over-reliance on imported energy sources by investing massively in renewables, not only because renewables are of climate change benefits, but because they offer a competitive alternative energy source.

\subsubsection{Experiences}

PPPs have been adopted by Morocco since 1997 with BOT arrangements which have helped the solar sector to speedily augment efforts being made to cut down over- 
dependence on other nations for its energy needs. To show full acceptance and understanding, the Moroccan government has created a law in 2014 that governs PPP operations [71], thereby boosting investor confidence and indicating the readiness of the government to mutualize agreements with the private sector. Solar is a big deal in Morocco as the best PV technology is utilized for electricity production, thereby boasting of some of the biggest solar installations in the world. A definite solar plan (Noor) has been employed by Morocco to help meet its target of $2000 \mathrm{MW}$ of installed solar capacity by 2020, a wide difference from its $180 \mathrm{MW}$ in 2015 [72].

\subsubsection{Successes}

Morocco has enjoyed a prestigious status globally when it comes to solar energy, boasting of the largest installations globally, partly due to the government's commitment to prioritize solar energy. PPPs have been a fundamental backbone to the execution of these projects. The selected one to be discussed in this section is the Ouarzazate Solar Power Station.

\section{The Ouarzazate Solar Power Station (OSPS)/Noor Power station}

The OSPS has been tagged as one of the flagship projects in the solar industry across the globe with the largest concentrated solar power station. The Moroccan government's commitment to ensure energy security and reduce over-dependence on other nations for energy has led to very bold solar projects. The OSPS is a three-phase project totaling $580 \mathrm{MW}$ that sits on the desert lands of Draa-Tafilalet, close to Ouarzazate. The 2500 hectares project benefits from the modern heated molten salt technology that stores up to $8 \mathrm{~h}$ of solar reserves which becomes beneficial during the night. This project supplies over one million homes with clean energy with other phases underway with the overall expectation of supplying clean energy to other European countries [72]. The stability and commitment of the government attracted partnership from the ACWA Power Ouarzazate on a PPP agreement to build, own, operate, and transfer (BOOT). ACWA power plays a major role in the Moroccan Agency for Solar Energy (MASEN)" as the major consortium [73].

The plant is well maintained to optimize its use by a subsidiary company of ACWA power (NOMAC). This project can boast of being a game-changer in the global solar scene due to the government's commitment and well-carved PPP laws as well as expertise in handling these agreements for a win-win at the end of the day. Between now and the year 2030, Morocco has set ambitious solar targets and a few among them are the already operational 470 MW Ain Beni Mathar Project (ABM), 500 MW Sebkhate Tah project, the 500 MW Focum Al-Oued project, the 800 MW Noor Midelt project among many others.

\subsubsection{Theoretical Perspective and Discussions}

Drawing from the experiences and progressions made in the solar industry of SA and Morocco, the Pareto optimality theory can be used as a tool for analysis. Both the government and private investors tend to mutually benefit without leaving one party worst off. Projects are carefully executed and guarded through the various stages of construction, operation, and maintenance for the benefit of society. At the end of the day, the returns on these projects are fully reaped, ensuring optimum satisfaction. It is evident that in both SA and Morocco, the principal and agent did not lose their original investments at the end of the projects, but have rather benefitted mutually. PO theory is therefore considered as a useful guide for efficient PPPs in both cases.

Another relevant theory through which the case of SA and Morocco can be accessed is the Game theory. The assumption that PPP is a game of fairness and a win-win for both parties has been essential in the accomplishment of the major solar projects highlighted above by both countries. Indeed, it is evident in both cases that contracts were awarded through competitive bidding processes and regular procurement procedures were followed. This ensured healthy competition and best practices resulting in value for money.

Although SA looks into the direction of aid and charity [74] to boost solar adoption in especially rural and poor areas, a rigorous effort is being made by the government and stakeholders to facilitate the wide spread of solar through fair PPP agreements. The cases 
presented in this paper further indicate the commitment towards ongoing solar projects and give a positive PPP trajectory for the future. Indeed, aid and charity have a place in solar adoption, they cannot be dwelled on as the major tool for advancing solar energy in SA.

The Principal-Agent problem has been consciously circumvented in both SA and Morocco through constant review of PPP agreements in their Solar sectors. In many instances, both the Principal and Agent have determined interest in various projects, hence do not put profitability ahead of the national interest. This gives a fair and leveraged ground for Solar PPPs to thrive without shedding additional incurred costs to the Principal.

The Parito Optimality and Game approaches are rather best for PPPs to thrive on, than the altruistic incline and principal-agent approach which tends to make the government over cautious due to the fear of being cheated at the end of the day. It can be concluded that drawing from the experiences of SA and Morocco, Ghana can potentially adopt the Game approach and PO theories as guides to help guarantee optimum efficiency in future PPPs to ensure the growth of its solar sector.

\section{Lessons from South Africa and Morocco}

\subsection{Lessons from South Africa}

PPPs in SA have been handled well over the past decades and as a result have led to the transformation of various sectors of the economy including energy, with a track record of about 123 major projects [75]. Although just like many other African countries, SA has its share of PPP systemic failures and a couple of contributing factors. However, within the African context, SA remains one of the most successful countries to have benefitted immensely from successful partnerships for both economic and infrastructural development. As part of the roadmap to SA's RE policy framework, solar technologies such as water heaters, concentrated solar power stations, apart from the major feed-in tariff scheme policy have helped SA make major strides in the solar sector.

The solid PPP framework adopted by the SA government has been the bedrock to the successful execution of projects. The private sector feels safe in investing in the country. The substantial progressive experiences gathered by both the public and private sectors make PPP more stable and accepted. SA has developed non-politically community-based PPPs to help augment bigger projects. Efforts are made to make procurement procedures as transparent and accountable as possible, thereby building trust. Ghana can emulate this structure, and develop a well-carved framework, enhance accountability and transparency to attract private participation in the solar industry.

\subsection{Lessons from Morocco}

PPP has almost gained unanimous support due to its usefulness in supporting development. Morocco has a solid PPP law that governs its operation. Due to the growing number of PPP agreements especially in the early 2000 s, Morocco found a need for a law in 2014. This gives clear-cut legislation to procurement, operation, and the issues that surround PPPs [71]. Investor confidence is boosted which guarantees solid legal protection due to standardization. Morocco mainly operates Build-Operate-Transfer (BOT) and BuildOwn-Operate-Transfer (BOOT) with well-organized and monitoring mechanisms put in place to ensure optimization. In Morocco, PPP agreements are given different attention than regular public facility management. Transparency, accountability, and standardization are basic benchmarks in Morocco [76].

Although not up to the standards of endowed countries such as the UK, Morocco has managed to integrate PPP into its finance ministry by ensuring a thorough favorable agreement for projects. Essential ways through which this was achieved is exposure to practical case studies and emulating countries with higher successes in PPPs. The government's commitment and support for PPP in Morocco are immeasurable and worthy of emulation. 


\section{Recommendations for Ghana}

The government of Ghana can begin to pay critical attention to PPP operations in the solar industry to get the best out of it for the country's energy security. A detailed legal framework must be developed to govern PPP activities in Ghana. This must be sufficient enough to cater for PPP at the district and local levels. Transparency, accountability, and standardization must be upheld in PPP operations in Ghana by the regulatory bodies and proper sanctions must be meted to individuals found culpable of self-aggrandizement and corruption.

Policies that prioritize private sector participation must be developed. The Private sector must feel safe and secure to invest in Ghana's solar sector without fear of being cheated, side-lined, or politically narrowed. Like in the case of Morocco and SA, favorable policies allow PPPs to thrive even at Community levels.

SA and Morocco have placed renewables at the heart of energy development, and solar features keenly due to the favorable climate. Ghana's government needs to place more premium on solar under the renewable energy development scheme and take full advantage of the sun for the benefit of society. Indeed, if the private sector finds Ghana's government committed enough, there can potentially be many bigger solar developments like in SA and Morocco.

Ghana can stand out like SA and Morocco when it comes to solar through PPPs by setting standards and desisting from the politicization of projects. Transparency, accountability, and communication with the public are key. Technical expertise in PPP must be sought in handling agreements to ensure optimum success and mutual benefit. The altruistic intent of the government to rely on aid, freeness, and support must be neutralized to a game win-win approach. This will reduce the pressure on the private sector and allow a free flow of investment.

Finally, the government must develop policies to handle issues about land litigations tactfully, and not leave it absolutely to the whims and caprice of traditional leaders and individual landowners. This will help reduce the trouble investors go through when it comes to land acquisition for solar projects in Ghana.

\section{Conclusions}

This paper has systematically discussed how Ghana's solar industry can be developed through PPPs. It draws some lessons from SA and Morocco that Ghana can emulate. There are gaps in the PPP structure of Ghana which need to be addressed to attract private participation in the solar sector.

This paper calls on the Ghanaian government to pay keen attention to Ghana's solar sector by developing a detailed legal framework for PPPs in the solar sector. It also highlights the need to develop a safe investment arena for the private sector; put an end to land litigations that discourage investors; encourage transparency; accountability and public engagement to ensure growth in Ghana's solar sector. Also, the Ghanaian government must consider the "Game approach and Parito Optimality" as guides to ensure that optimum and mutual benefits are received for both investors and the State. Ghana's solar sector can become one of the best on the continent if PPP is given all the attention it deserves, and the recommendations made in this paper are considered. This paper forms a solid base for future research works such as; the politics of land ownership in Ghana and its impact on PPP; the prospects of solar PPPs in Ghana and affected public participation for community solar projects in Ghana.

Author Contributions: Conceptualization, S.A.A.; methodology, S.A.A.; validation, A.B., F.M.-S. and N.S.; formal analysis, S.A.A.; investigation, S.A.A.; resources, S.A.A., A.B., F.M.-S. and N.S.; data curation, S.A.A.; writing —original draft preparation, S.A.A.; writing-review and editing, S.A.A., A.B., F.M.-S. and N.S.; visualization, S.A.A. and F.M.-S.; supervision, A.B., F.M.-S. and N.S.; funding acquisition, S.A.A. and F.M.-S. All authors have read and agreed to the published version of the manuscript. 
Funding: This study was funded by the Ghana Scholarships Secretariat an organization under the office of the president of the republic of Ghana. F.M.-S. would like to thank Edinburgh Napier University for funding his time under Project 2706622. The views and opinions expressed therein are those of the authors and do not necessarily reflect the funding bodies.

Institutional Review Board Statement: Not applicable.

Informed Consent Statement: Not applicable.

Data Availability Statement: Not applicable.

Conflicts of Interest: The authors declare no conflict of interest. The funders had no role in the design of the study; in the collection, analyses, or interpretation of data; in the writing of the manuscript, or in the decision to publish the results.

\section{References}

1. Liu, Y.; Lu, Z.; Yang, F. The investigation of solar PV models. In Proceedings of the 2018 IEEE Power and Energy Society Innovative Smart Grid Technologies Conference (ISGT), Washington, DC, USA, 19-22 February 2018; IEEE: Piscatway, NJ, USA; pp. 1-5.

2. Asumadu-Sarkodie, S.; Owusu, P.A. Multivariate co-integration analysis of the Kaya factors in Ghana. Environ. Sci. Pollut. Res. 2016, 23, 9934-9943. [CrossRef]

3. Grossmann, W.; Grossmann, I.; Steininger, K.W. Solar electricity supply isolines of generation capacity and storage. Proc. Natl. Acad. Sci. USA 2015, 112, 3663-3668. [CrossRef] [PubMed]

4. World Bank. Ghana-Access To Electricity (\% of Population). Available online: https://data.worldbank.org/indicator/EG.ELC. ACCS.ZS?locations=GH (accessed on 20 April 2021).

5. Hay, J.E.; Wardle, D.I. An assessment of the uncertainty in measurements of solar radiation. Sol. Energy 1982, 29, 271-278. [CrossRef]

6. World Energy Outlook 2013-Analysis-IEA. Available online: https://www.iea.org/reports/world-energy-outlook-2013 (accessed on 1 December 2021).

7. Lighting Up Africa: Bringing Renewable, Off-Grid Energy to Communities. Available online: https://www.worldbank.org/en/ news / feature/2020/08/13/lighting-up-africa-bringing-renewable-off-grid-energy-to-communities (accessed on 1 December 2021).

8. Bellini, E. Ghana Comissions 20 MW Solar Park, Plans Auctions for IPP Projects-Pv Magazine International. Available online: https:/ / www.pv-magazine.com/2018/09/17/ghana-comissions-20-mw-solar-park-plans-auctions-for-ipp-projects / (accessed on 30 March 2021).

9. Haanyika, C.M. Rural electrification policy and institutional linkages. Energy Policy 2006, 34, 2977-2993. [CrossRef]

10. Ghadimi, H. Book Review: Energy-Based Economic Development: How Clean Energy Can Drive Development and Stimulate Economic Growth. Econ. Dev. Q. 2017, 31, 92-93. [CrossRef]

11. Kemausuor, F.; Obeng, G.Y.; Brew-Hammond, A.; Duker, A. A review of trends, policies and plans for increasing energy access in Ghana. Renew. Sustain. Energy Rev. 2011, 15, 5143-5154. [CrossRef]

12. Bukari, D.; Tuokuu, F.X.D.; Suleman, S.; Ackah, I.; Apenu, G. Ghana's energy access journey so far: A review of key strategies. Int. J. Energy Sect. Manag. 2020, 15, 139-156. [CrossRef]

13. Owusu, P.A.; Asumadu-Sarkodie, S. A review of renewable energy sources, sustainability issues and climate change mitigation. Cogent Eng. 2016, 3, 1167990. [CrossRef]

14. Jumbe, C.B.L.; Msiska, F.B.M.; Madjera, M. Biofuels development in Sub-Saharan Africa: Are the policies conducive? Energy Policy 2009, 37, 4980-4986. [CrossRef]

15. Tang, X.; Liao, H. Energy poverty and solid fuels use in rural China: Analysis based on national population census. Energy Sustain. Dev. 2014, 23, 122-129. [CrossRef]

16. Vesalon, L.; Creţan, R. Mono-industrialism and the Struggle for Alternative Development: The Case of the Roşia Montană Gold-mining Project. Tijdschr. voor Econ. en Soc. Geogr. 2013, 104, 539-555. [CrossRef]

17. Permyakov, M.B.; Krasnova, T.V. Alternative Energy Sources in Resolving Environmental Problems and Providing Safety of Single-Industry Towns. IOP Conf. Series Mater. Sci. Eng. 2020, 972, 012026. [CrossRef]

18. Adanu, K.G. Promoting photovoltaic electricity usage in developing countries-Experience from Ghana. Sol. Energy Mater. Sol. Cells 1994, 34, 67-71. [CrossRef]

19. Adanu, K.G. Photovoltaic electricity in Ghana-Current use and potential for the future. Renew. Energy 1991, 1, 823-826. [CrossRef]

20. Hodge, G.A.; Greve, C. Public?Private Partnerships: An International Performance Review. Public Adm. Rev. 2007, 67, 545-558. [CrossRef]

21. Linder, S.H. Coming to Terms With the Public-Private Partnership. Am. Behav. Sci. 1999, 43, 35-51. [CrossRef]

22. Scharle, P. Public-Private Partnership (PPP) as a social game. Innov. Eur. J. Soc. Sci. Res. 2002, 15, 227-252. [CrossRef]

23. Alidu, S. Public Private Partnerships in Ghana: Interrogating the Efficacy of a Politically Convenient Practice; Friedrich Ebert Stiftung: Accra, Ghana, 2018; ISBN 9988572980. 
24. Hodge, G.A. Risks in Public-Private Partnerships: Shifting, Sharing or Shirking? Asia Pac. J. Public Adm. 2004, 26, 155-179. [CrossRef]

25. Government Objectives: Benefits and Risks of PPPs. Available online: https://ppp.worldbank.org/public-private-partnership/ overview / ppp-objectives (accessed on 31 March 2021).

26. Witesman, E.M.; Fernandez, S. Government Contracts With Private Organizations. Nonprofit Volunt. Sect. Q. 2013, 42, 689-715. [CrossRef]

27. Hodge, G.A. Privatisation. Altern. Law J. 2002, 27, 177-183. [CrossRef]

28. Osborne, S.P. Public-Private Partnerships: Theory and Practice in International Perspective; Routledge: London, UK, 2000.

29. Tadesse, A.G. 600 Million Africans Go without Electricity: IEA Chief. Available online: https://www.aa.com.tr/en/africa/600million-africans-go-without-electricity-iea-chief/1502097 (accessed on 31 March 2021).

30. Farlam, P. Assessing Public-Private Partnerships in Africa; South African Institute of International Affairs (SAIIA): Johannesburg, South Africa, 2005.

31. Vollgraaff, R. AfDB Seeks to Plug Africa \$170 Billion Infrastructure Needs-Bloomberg. Available online: https:/ /www.bloomberg. com/news/articles/2018-05-08/afdb-seeks-funds-to-plug-africa-170-billion-infrastructure-gap (accessed on 1 April 2021).

32. Mustafa, A. Public-Private Partnerships in Sub-Saharan Africa: Challenges and Opportunities. J. Struct. Finance 2015, 21, 55-59. [CrossRef]

33. Yescombe, E.R. Public-Private Partnerships in Sub-Saharan Africa Case Studies for Policymakers 2017; Uongozi Institute: Dar es Salaam, Tanzania, 2018.

34. Amonya, F. Public-Private Partnerships (PPP) in Africa: Harking the Holonomic. SSRN Electron. J. 2018, 1-14. [CrossRef]

35. Public-Private Partnerships. Available online: https://www.worldbank.org/en/topic/publicprivatepartnerships (accessed on 1 April 2021).

36. Lynn, L.E. The Oxford Handbook of Public Management; Pollitt, C., Ferlie, E., Lynn, L.E., Eds.; Oxford University Press: Oxford, UK, 2005; ISBN 9780199259779/0199259771.

37. Deryabina, M. Public-private partnership: Theory and practice. Vopr. Ekon. 2008, 8, 61-77. [CrossRef]

38. Ghana PPP Portal. Available online: http://ppp.mofep.gov.gh/ (accessed on 1 April 2021).

39. Robert, O.K.; Dansoh, A.; Ofori-Kuragu, J.K. Reasons for adopting Public-Private Partnership (PPP) for construction projects in Ghana. Int. J. Constr. Manag. 2014, 14, 227-238. [CrossRef]

40. Akintoye, A.; Hardcastle, C.; Beck, M.; Chinyio, E.; Asenova, D. Achieving best value in private finance initiative project procurement. Constr. Manag. Econ. 2003, 21, 461-470. [CrossRef]

41. Osei-Kyei, R.; Chan, A.P.C.; Javed, A.A.; Ameyaw, E.E. Critical success criteria for public-private partnership projects: International experts' opinion. Int. J. Strat. Prop. Manag. 2017, 21, 87-100. [CrossRef]

42. Laffont, J.-J.; Tirole, J. A Theory of Incentives in Procurement and Regulation; MIT Press: Cambridge, MA, USA, 1993; ISBN $9780262121743 / 0262121743$.

43. Sannikov, Y. A Continuous-Time Version of the Principal-Agent Problem. Rev. Econ. Stud. 2008, 75, 957-984. [CrossRef]

44. Shavell, S. Risk Sharing and Incentives in the Principal and Agent Relationship. Bell J. Econ. 1979, 10, 55. [CrossRef]

45. Fayezi, S.; O'Loughlin, A.; Zutshi, A. Agency theory and supply chain management: A structured literature review. Supply Chain Manag. Int. J. 2012, 17, 556-570. [CrossRef]

46. Doucouliagos, C. A Note on the Evolution of Homo Economicus. J. Econ. Issues 1994, 28, 877-883. [CrossRef]

47. Glennie, J. The Trouble with Aid: Why Less Could Mean More for Africa-Jonathan Glennie; Zed Books: London, UK, 2010; ISBN 9781848135017.

48. Altruism (Stanford Encyclopedia of Philosophy). Available online: https://plato.stanford.edu/entries/altruism/ (accessed on 1 April 2021).

49. Friedland, J.; Emich, K.; Cole, B.M. Uncovering the moral heuristics of altruism: A philosophical scale. PLoS ONE 2020, 15, e0229124. [CrossRef] [PubMed]

50. Cui, C.; Liu, Y.; Hope, A.; Wang, J. Review of studies on the public-private partnerships (PPP) for infrastructure projects. Int. J. Proj. Manag. 2018, 36, 773-794. [CrossRef]

51. Atkinson, R. Altruism in Nonprofit Organizations Altruism in Nonprofit Organizations; Florida State University: Tallahassee, FL, USA, 1990.

52. Fudenberg, D.; Levine, D.K. Whither Game Theory? Towards a Theory of Learning in Games. J. Econ. Perspect. 2016, 30, 151-170. [CrossRef]

53. Myerson, B.R. Game Theory; Harvard University Press: Cambridge, MA, USA, 2013; ISBN 9780674728615/0674728610.

54. Ouenniche, J.; Boukouras, A.; Rajabi, M. An Ordinal Game Theory Approach to the Analysis and Selection of Partners in Public-Private Partnership Projects. J. Optim. Theory Appl. 2016, 169, 314-343. [CrossRef]

55. Edkins, M.; Marquard, A.; Winkler, H. South Africa's Renewable Energy Policy Roadmaps; Energy Research Centre (ERC): Cape Town, South Africa, 2010.

56. IRENA Renewable Capacity Statistics 2020. Available online: https:/ / publications/2020/Mar/Renewable-Capacity-Statistics-20 20 (accessed on 1 April 2021).

57. South Africa's Energy Policies: Are Changes Finally Coming? FRI-Institut Français des Relations Internationales. Available online: https:/ / www.ifri.org/en/publications/editoriaux-de-lifri/edito-energie/south-africas-energy-policies-are-changesfinally (accessed on 1 April 2021). 
58. Green Cape Smart Electricity. Available online: https://www.greencape.co.za/content/focusarea/smart-electricity (accessed on 1 April 2021).

59. Johnson, F.X.; Takama, T. Economics of modern and traditional bioenergy in african households: Consumer choices for cook stoves. In Bioenergy for Sustainable Development in Africa; Springer: Berlin, Germany, 2012; pp. 375-388. ISBN 9789400721814.

60. De Aar Project 2 Done by Solar Capital in South Africa. Available online: https://www.solarcapital.co.za/our-projects/de-aar-3project-2/ (accessed on 1 April 2021).

61. Power Technology The Biggest Solar Projects in Africa. Available online: https://www.power-technology.com/features/thebiggest-solar-projects-in-africa/ (accessed on 1 April 2021).

62. Solar Farms Promote Literacy. Available online: https://www.news24.com/news24/southafrica/local/express-news/solarfarms-promote-literacy-20160405 (accessed on 1 April 2021).

63. Unwin, J. Solar Power in South Africa: What Are Its Leading Plants? 2019. Available online: https://www.power-technology. com/features/solar-power-south-africa/ (accessed on 1 April 2021).

64. KaXu Solar One, Northern Cape-Power Technology. Energy News and Market Analysis. Available online: https://www.powertechnology.com/projects/kaxu-solar-one-northern-cape/ (accessed on 1 April 2021).

65. Telsnig, T.; Eltrop, L.; Winkler, H.; Fahl, U. Efficiency and costs of different concentrated solar power plant configurations for sites in Gauteng and the Northern Cape, South Africa. J. Energy South. Afr. 2013, 24, 77-89. [CrossRef]

66. Andrew, M.; Fabricius, C.; Timmermans, H. An Overview of Private Sector-Community Partnerships in Forestry and Other Natural Resources in the Eastern Cape; Unpublished Report for the Forest Enterprise Development Office; Hunting Technical Services and Environmentek, Council for Scientific and Industrial Research: London, UK; Pretoria, South Africa, 2000.

67. Budds, J.; Mcgranahan, G. Are the Debates on Water Privatization Missing the Point? Experiences from Africa, Asia and Latin America. Environ. Urban. 2003, 15, 87-114. [CrossRef]

68. Reports of Backsheet Failures at 75 MW Mulilo Sonnedix Prieska solar Farm in South Africa-Pv Magazine International. 2020. Available online: https://www.pv-magazine.com/2020/02/11/reports-of-backsheet-failures-at-75-mw-mulilo-sonnedixprieska-solar-farm-in-south-africa/ (accessed on 1 April 2021).

69. Adam, J. Morocco Is Building a Giant Thermosolar Farm in the Sahara Desert. World Economic Forum. 2018. Available online: https: / / www.weforum.org/agenda/2018/05/morocco-is-building-a-solar-farm-as-big-as-paris-in-the-sahara-desert / (accessed on 1 April 2021).

70. Morocco, an Emerging Economy with Energy Challenges. Planète Énergies. 2016. Available online: https://www.planeteenergies.com/en/medias/saga-energies/morocco-emerging-economy-energy-challenges (accessed on 1 April 2021).

71. New Moroccan PPP Law. White \& Case LLP_JDSupra. 2015. Available online: https://www.jdsupra.com/legalnews/newmoroccan-ppp-law-98584/ (accessed on 1 April 2021).

72. Noor Ouarzazate Solar Complex, Morocco. 2021. Available online: https://www.power-technology.com/projects/noorouarzazate-solar-complex/ (accessed on 1 April 2021).

73. Noor Solar Power in Morocco-ECOHZ. 2021. Available online: https://www.ecohz.com/renewable-energy-solutions/ powerplants/noor-solar-power-in-morocco/ (accessed on 1 April 2021).

74. SolarAid. Combatting Poverty and Climate Change. 2021. Available online: https://solar-aid.org/ (accessed on 7 December 2021).

75. South Africa. PPP Knowledge Lab. 2021. Available online: https://pppknowledgelab.org/countries/south-africa (accessed on 1 April 2021).

76. Wahib, L. Public Private Partnership in Morocco: What Lessons to Be Learned from the UK Private Finance Initiative? LinkedIn. 2019. Available online: https:/ / www.linkedin.com/pulse/public-private-partnership-moroccowhat-lessons-learned-wahib/ (accessed on 1 April 2021). 